\title{
CORRECTION
}

\section{Correction to: Waste is not a service}

\author{
Jeroen Guinée ${ }^{1} \cdot$ Reinout Heijungs ${ }^{1,2}$
}

Published online: 4 November 2021

(c) The Author(s) 2021

\section{Correction to: The International Journal of Life Cycle Assessment (2021) 26:1538-1540 https://doi.org/10.1007/s11367-021-01955-5}

The original version of this article unfortunately contained a mistake which was missed during typesetting. In both Figs. 1 and 2 several lines were missing arrowheads. The correct versions of Figs. 1 and 2 are given below.

The original article has been corrected.

Open Access This article is licensed under a Creative Commons Attribution 4.0 International License, which permits use, sharing, adaptation, distribution and reproduction in any medium or format, as long as you give appropriate credit to the original author(s) and the source, provide a link to the Creative Commons licence, and indicate if changes were made. The images or other third party material in this article are included in the article's Creative Commons licence, unless indicated otherwise in a credit line to the material. If material is not included in the article's Creative Commons licence and your intended use is not permitted by statutory regulation or exceeds the permitted use, you will need to obtain permission directly from the copyright holder. To view a copy of this licence, visit http://creativecommons.org/licenses/by/4.0/.

Publisher's Note Springer Nature remains neutral with regard to jurisdictional claims in published maps and institutional affiliations.

The original article can be found online at https://doi.org/10.1007/ s11367-021-01955-5.

Jeroen Guinée

guinee@cml.leidenuniv.nl

1 Institute of Environmental Sciences (CML), Leiden

University, Einsteinweg 2, 2333 CC Leiden, The Netherlands

2 Department of Operations Analytics, Vrije Universiteit Amsterdam, De Boelelaan 1105, 1081 HV Amsterdam, The Netherlands 
Fig. 1 (a) The traditional textbook view of the productionuse-disposal sequence; (b) the way it is implemented in ecoinvent $\mathrm{v} 2$, with a disposal process delivering a waste treatment service (WTS); (c) the way it has been implemented in ecoinvent $\mathrm{v} 3$ delivering a WTS but expressed as physical waste flow

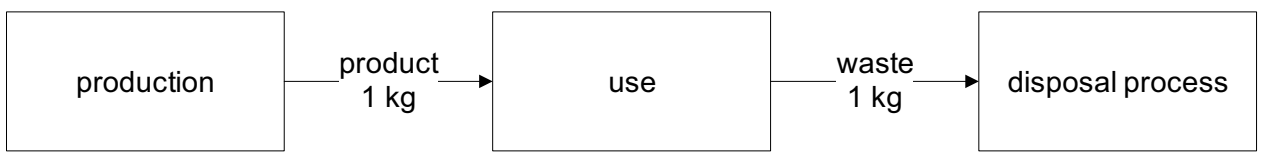

(a)
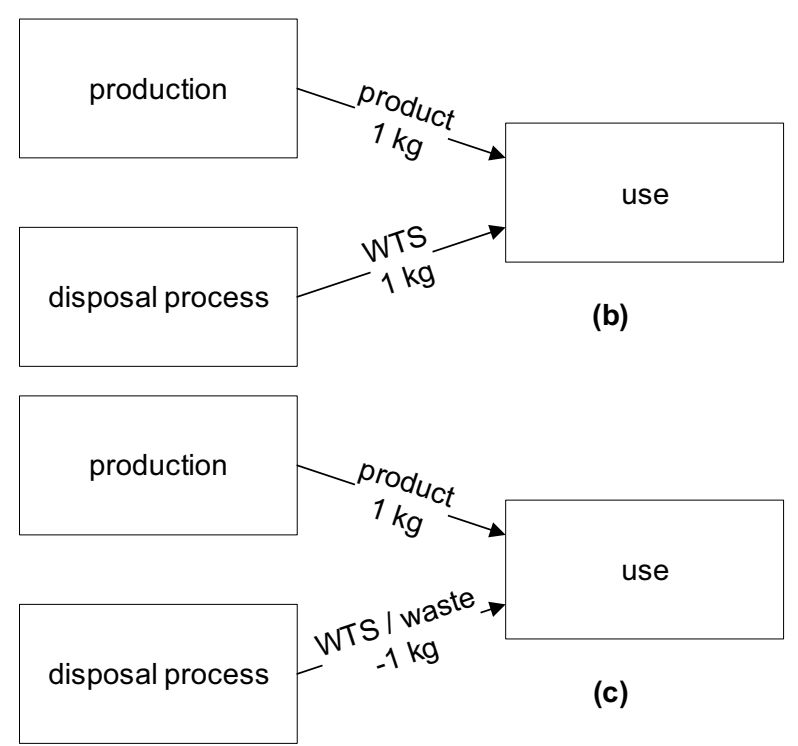

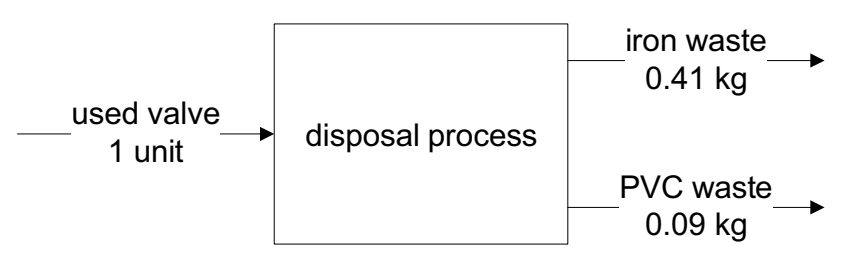

(a)

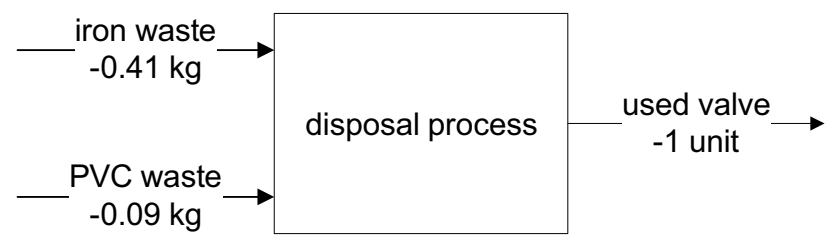

(b)

Fig. 2 (a) The traditional textbook view of a particular disposal process that transforms a waste into materials; (b) the way this process is implemented in ecoinvent $\mathrm{v} 3$ 